\title{
Foreign Direct Investment (FDI) and Natural Resources: Blessing or Curse? Empirical Evidence from the Gulf Cooperation Council (GCC)
}

\author{
Mohamed Elheddad ${ }^{1}$, Resham Thapa-Parajuli ${ }^{2}$ and Majed Alharthi ${ }^{3, *}$ \\ ${ }^{1}$ Scholars School System University and College Center - in Partnership with Leeds Trinity University, Leeds, \\ UK \\ ${ }^{2}$ Central Department of Economics, Tribhuvan University, and Global Institute for Interdisciplinary Studies, \\ Nepal \\ ${ }^{3}$ Finance Department, College of Business, King Abdulaziz University, Rabigh, P.O. BOX. 344, Zip Code \\ 21911, Saudi Arabia
}

\begin{abstract}
This paper investigates why foreign direct investment (FDI) inflows are disproportionate among resource and non-resource sectors in oil-rich countries over the period 1980-2017. We constructed a balanced panel of data for Gulf Cooperation Council (GCC) countries from the database of the United Nations Conference on Trade and Development (UNCTAD) and disaggregate data from The Financial Times. We regress total and sectoral FDI inflows on oil rents to a GDP ratio, controlling other socio-economic variables. Our results first consider oil rents. This proxy for natural resources is negatively associated with total FDI inflows. The oil rents/GDP share and resource-based FDI have a significantly positive correlation. However, the adverse effect of oil rents remains true in the case of the non-resource sector foreign investment. Second, oil price fluctuations lead to a rise in the non-resource FDI but discourage resource-related FDI inflows. These empirical results confirm that FDI-Natural resources curse through the crowd-out effect of natural resources in the Gulf Cooperation Council (GCC) countries. Our results are robust to different panel data estimators.
\end{abstract}

Keywords: Foreign Direct Investment, natural resources curse, oil, panel data regression, endogeneity, Gulf Cooperation Council (GCC).

\section{INTRODUCTION}

Policymakers, governments and academicians have a widespread thought that foreign direct investments (FDIs) influence positive productivity for host countries, in particular developing economies. The key channels for these externalities are transferring the new technologies to the host country, creating new job opportunities, providing finance tools for the new projects and creating links between foreign and domestic firms (Alfaro et al., 2004; Borensztein et al., 1998). According to their rent-seeking FDI behaviour, Multinational Corporations (MNCs) directed their investments toward resource-abundant economies because of their high profitability in the oil industry (Kolstad and Wiig, 2013).

However, recent empirical studies and international reports argue that resource-rich economies attract a lower amount of FDI-inflows than countries with poor resources (Poelhekke \& Van der Ploeg, 2010; Poelhekke \& van der Ploeg, 2013). Statistics show that the FDI ratio in African resource-lacking countries

*Address correspondence to this author at the Finance Department, College of Business, King Abdulaziz University, Rabigh, P.O. BOX. 344, Zip Code 21911, Saudi Arabia; Tel: +966 12 6400000; Fax: +966 12 6952437;

E-mail: mdalharthi@kau.edu.sa

JEL Classifications: F21, N5, O13, O41, C33, C23, C26 outpaces African resource-abundant countries in the last 15 years (Economist, 2015). Moreover, IMF statistics indicate that the FDI/GDP ratio in the Organisation for Economic Co-operation and Development (OECD) region is larger than the one for the OPEC countries. The sectoral level of the FDl's path also shows a similar declining trend, as seen during 2008 and 2014 when the FDI-inflows towards the primary sector declined significantly.

FDI inflows in countries with rich resources focus on natural resources sectors (e.g. energy, diamond, gas or gold). Investing in these industries might generate an ambiguous effect on the host country. Due to high profits and high wages in this sector, production factors (capital and labour) tend to move from the nonresource sector, such as manufacturing and servicing, to the booming sector, negatively impacting the other sector's productivity. This is the crowding-out effect of natural resources or de-industrialisation (Corden and Neary, 1982). At the same time, the price of these commodities is highly volatile; this volatility makes this sector associated with high uncertainty. Thus, natural resources abundance could be a curse rather than a blessing regarding FDI spill-overs.

Interestingly, few studies investigate the association between FDI and natural resources. More specifically, 
sectoral FDI determinants are rarely studied. This paper aims to identify the impacts of oil rent as a proxy for natural resources over FDI-inflows to resource and non-resource sector. Also, this paper investigates the relationship between oil price fluctuations and foreign investors in both the oil and non-oil sectors.

Gulf Cooperation Council (GCC) region is an interesting case study because it receives over 50 percent of FDI inflows in the Middle East. Regarding FDI composition, Saudi Arabia-the largest GCC economy and the second-largest oil producer in the world-has over 70 percent of FDI inflows directed to the oil sector. The Qatari oil sector attracts about 65 percent of total FDI inflows. Although attracting FDI inflows to all the sectors is important to satisfy the growing world's demand for oil products, the FDI on oilrich economies to the non-oil sector is also important for economic diversification. Thus, this study attempts to study the impacts of natural resources on the volume and distribution of FDI. In particular, this paper identifies the existence of an 'FDI-natural resources curse' (Asiedu, 2013).

A brief examination of available data regarding GCC countries points out a significant negative correlation $(-0.35)$ between total FDI and oil rents during 19802017. Figure 1 shows the scattered plots between FDI inflows and abundant natural resources measured by oil rents. An increase in oil rents discourages foreign firms in the GCC. This puzzling relationship motivated us to investigate the sources of this negativity. Therefore, this paper answers two main questions: in re-examining Asiedu's (2013) question regarding natural resources crowding-out FDI and is there an FDI-natural resource curse? If yes, what is the mechanism? And what is the relationship between oil price fluctuations and both aggregate FDI and disaggregate FDI?

This study contributes to the ongoing literature in several aspects. It first relates to natural resources curse studies by providing a new mechanism on how FDI could be an additional channel of the natural resources curse. MNCs focused their investments mainly on the oil sector, which leads to transferring factors of production from the sector that does not include resources (manufacturing and servicing) to the profitable sector (oil). As a result, this process causes a reduction of $\mathrm{FDI}$-inflows to the non-resource sectors and creates the crowding-out effect. Secondly, this study also offers a great understanding of FDI determinants, including natural resources as a factor.

The main findings of this empirical study are as follows: first, aggregate FDI data show that natural resources measured as an oil/rents ratio have negative effects on FDI inflow to GCC countries. Second, when focusing on the mechanism of this negativity, disaggregate data of FDI inflows illustrate that natural resources attracted more FDI to resource sectors and deterred FDI to non-resource industries, which causes the crowding-out effect. Third, the volatility of oil prices affects resource-FDI significantly and negatively.

The rest of the paper is structured as follows, section2 reviews the literature that related to the FDI-

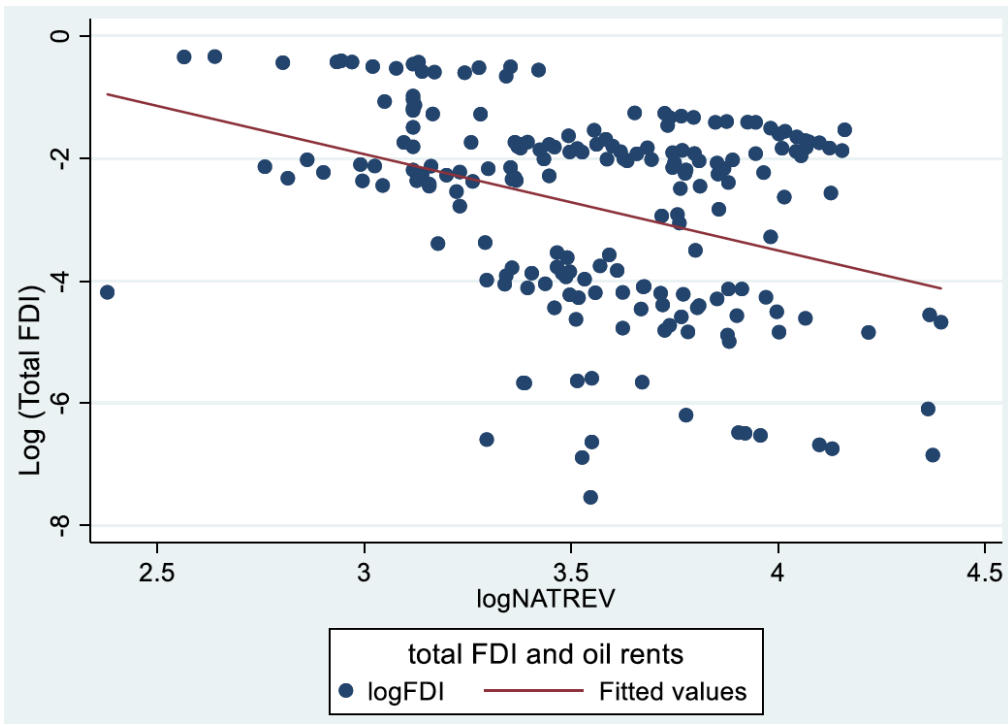

Figure 1: Total FDI-natural resource rents correlation.

Source: Authors' work based on World Bank Indicators dataset, World Bank. 
natural resource relationship. Section 3 presents the methodology and data sources. Empirical results are presented in section 4 . Finally, section five summarises the main findings and conclusions with some plausible policy implications.

\section{LITERATURE REVIEW}

Dunning (1998) focused on the motivations of MCNs. A flood of papers emerged that examine and analyse the possible factors which attract or deter foreign investors. Most of these studies focused their attention mainly on determinants of aggregate FDI inflows such as Asiedu (2002, 2006), Dunning (2001), Froot and Stein (1989), Lipsey and Weiss (1981), Wheeler and Mody (1992) and many more. Unfortunately, sectoral determinants of FDI is insufficiently investigated. In particular, the association between natural resource abundance and foreign firms' decisions of investment have not been extensively examined.

The influence of natural resource abundance on FDI inflows is far from conclusive. This relationship follows two paths. The first school believes that natural resource is a key factor for attracting FDI inflows. Some studies such as Asiedu (2002, 2006), Bokpin et al. (2015), Mohamed and Sidiropoulos (2010) found that natural resources boost the outward FDI to host countries. These studies claim that investments in such extractive industries create very high profits, especially in resource-rich developing economies with low-quality institutions and low environmental regulations. Thus, MNCs direct their investments to these economies.

However, the second school of thoughts argue that natural resources could deter FDI such as Poelhekke and van der Ploeg (2013) and Elheddad (2018). This argument supported the natural resources curses hypothesis. When FDI concentrated on one booming sector (oil) lead to other production factors, especially capital (foreign and domestic) and labour to move them to the oil sector. This process creates a negative effect on the industrial and service sectors (productive sectors). The third category of papers investigated the indirect effects of a natural resource on FDI (Hayat, 2018).

Asiedu (2006) examined the influence of natural resource availability on total FDI inflows. This study concentrated on Sub-Saharan African countries from 1984-2002. The main results show that natural resources support FDI inflows significantly and positively. Similarly, Bokpin et al. (2015) utilised oil rents, mineral rents and forest rents of 49 African countries and arrived in the same relationship.

In the case of the Middle East and North African (MENA) countries, Mohamed and Sidiropoulos (2010) found that natural resources are the key elements for investing MNCs.

According to the literature, the study of Poelhekke and van der Ploeg (2013) adopted the curse of FDInatural resources. The main finding of this study proposes that the oil rent attracts more FDI outflow to the oil sector but discourages FDI in the non-oil sector. This current paper benefits from firm-level data on outward FDI from Dutch companies to 183 developing economies.

Asiedu (2013) confirmed the adverse relationship between natural resources abundance represented by oil rents and oil exports on inward FDI, utilising the data from 120 developing countries. Asiedu (2013) said that this negative association was because of the persistence level of fluctuation in oil prices. Such instability in oil price creates a high level of risks and might have low FDI. This leads us to review some papers about the impact of oil price volatility and FDI inflows.

A recent empirical study on 35 economies finds that countries that depend mainly on commodities with high price fluctuations experience more volatility in trade, have less economic growth and attract low foreign direct investments compared with countries that specialise in stable price goods (Blattman et al., 2007). Also, less diversified countries, particularly countries with rich resources, lag concerning economic development.

Based on the above arguments, this study puts forward a hypothesis that some oil-rich economies such the GCC counties abundance with oil attracts more foreign investments to the oil sector, but deters the non-oil FDI (manufacturing and service sector).

Therefore, a high dependency on the oil sector increases high risk in the host economy. This risk is reflected by the volatility of oil prices. Particularly, oilFDI inflows to the host country go out because of any fluctuation in the oil price. The pioneering work by Henry (1974) and Bernanke (1983) investigated the association between oil price uncertainty and the behaviour of investments. Both studies conclude that a high level of volatility in oil prices leads to a low level of 
investments. Hamilton (2003) arrived at the same relationship, which the inverse relationship between oil uncertainty and investments. In his study, he argues that high fluctuations decrease the consumer's expenditure on durable goods, such as transportation and housing, which negatively impacts the firm's investments.

The most closely-related work to the present study is Van der Ploeg (2009), who first introduced volatility as a main indicator for the resource curse. They found in this study that GDP per capita volatility hurts economic growth. Blattman et al. (2007) found that the correlation between oil price volatility and FDI is significant and inverse. A high level of oil price volatility leads to low resource-related FDI. This study tests whether a high level of oil price volatility leads to low resource-FDI inflows. Hence, this stud hypothesizes that higher oil price volatility leads to low resource-FDI.

\section{DATA, METHODOLOGY AND MODEL SPECIFICATIONS}

The variables examined in this study are selected based on the FDI theories and previous papers on FDI determinants. This study benefits from panel data on FDI determinants for six GCC countries that consider being oil exporters. These countries are the Kingdom of Bahrain, Kuwait, Oman Sultanate, Qatar State, the Kingdom of Saudi Arabia and the United Arabs Emirates. This paper utilises two different data sets on FDI inflows. The first is the United Nations Conference on Trade and Development (UNCTAD) data set covering the period of $1980-2017$ for total FDI inflows in GCC. The UNCTAD defined the stock of FDI (both inward and outward). "For associate and subsidiary enterprises, it is the value of the share of their capital and reserves (including retained profits) attributable to the parent enterprise (this is equal to total assets minus total liabilities), plus the net indebtedness of the associate or subsidiary to the parent firm. For branches, it is the value of fixed assets and the value of current assets and investments, excluding amounts due from the parent, fewer liabilities to third parties" UNCTAD, 2018,). This variable and factor were collected from UNCTAD database.

Second, the greenfield FDI was extracted from fDi Markets, which is related to fDi Intelligence that is a part of The Financial Times Group. Besides, fDi Markets is a considered being one of the most important data sources for UNCTAD, Economist Intelligence Unit and World Bank. FDi Markets verify and tracing for an individual's greenfield investments project (cross-borders) from 2003. This database provides the investments value and the number of job creations. One of the most important advantages for this data is that it has lower effects through measurement problems (Canton and Solera, 2016).

However, the data extracted from The Financial Times consist of about 35 sectors. This study concentrated on two important sectors: resource (e.g. energy, oil and gold) and non-resource (i.e. manufacturing). This study contains the FDI inflow as resources of coal, oil, natural gas, minerals and metals, whereas the non-resource sector is represented in a production of goods (secondary sector) and services (tertiary sector).

Table 1: List of Variables, Symbols, and their Measurement

\begin{tabular}{|c|c|c|}
\hline Name and measurement & Mean & 1.63 \\
\hline \hline Log (Total FDI) & -2.76 & 1.19 \\
\hline Log (Resource FDI) & 2.77 & 0.57 \\
\hline Loga (Non-resource FDI) & 3.20 & 0.35 \\
\hline Log (Oil Rents) & 3.65 & 3.65 \\
\hline Inflation Rate & 3.81 & 1.00 \\
\hline Loga (Labour Force) & 7.40 & 1.08 \\
\hline Log (Trade Openness) & 1.02 & 0.53 \\
\hline Log (GDP Per Capita) & 10.09 & 0.55 \\
\hline Political Instability Index (PI) & 2.00 & 0.41 \\
\hline Corruption Perception Index (CPI) & 3.55 & 1.78 \\
\hline Oil Price fluctuation (SD) & 8.66 & \\
\hline
\end{tabular}

\#Standard Deviation. 
Another key variable is the natural resources proxy. This paper uses an oil rents variable, which is used to share gross domestic production for natural resource variables. This choice is based on its exogeneity, thus this variable help to mitigate the problem of endogeneity. Oil rents are collected from World Economic Indicators (WDI). Table 1 gives information about some descriptive statistics for all used variables.

For further robustness, we control institutional, political and macroeconomics factors. The variables of corrupted perception and political instability were collected from the ICRG dataset. While the inflation rate represents the stability of the economy, GDP per capita shows the size of the economy and trade openness, indicating the status of international trade. All the mentioned variables were collected from World Economic Indicators WDI.

Checking the panel unit root tests have received significant attention for the long panel data analysis (when time $(T)$ greater than several panels $(N)$ ). Therefore, it is important to test for stationarity of variables which is used in this study. Performing the stationarity test could help us to avoid the problem of incorrectly specifying the model and spurious regressions. This study applies the Hadri (2000) unit root test. Unlike the other panel unit root test such as the Levin-Lin-Chu test and the Im-Pesaran-Shin test, the Hardi test argues that the null hypothesis is that no unit root.

Panel unit root test is presented in Table 2. This table shows that the null hypothesis is accepted at the 5 percent level of significance for all series at the level, but it is rejected at the first difference. This confirms that all series are stationary at the first difference.
Since all variables are integrated in the same order I(1), the next step is to test for a long-run relationship. This paper performs two main co-integration tests: Kao and Pedroni. Table 3 summarises the results of these tests. Kao residual test shows that the null hypothesis "no co-integration" is rejected at a 5 percent level of significance. Similarly, Pedroni test confirms the longrun correlation amongst these variables. Therefore, this relationship must be estimated to check the impacts of determinants on FDI inflows.

The general model for the testing association between FDI inflows and their determinants could be specified, as in the Poelkke and van der Ploeg (2010, 2013) regression that explains a model as an econometric for total FDI, FDI resources and FDI nonresources:

$$
\begin{aligned}
& \log \left(\text { FDItotal }_{i, t}\right)=\alpha_{0}+\alpha_{1} \log \left(\text { Nat }_{i, t}\right)+\alpha_{4} X_{i, t}+\varepsilon_{1 i, t} \\
& \log \left(\text { FDIR }_{i, t}\right)=\alpha_{0}+\alpha_{1} \log \left(\text { Nat }_{i, t}\right)+\alpha_{4} X_{i, t}+\varepsilon_{2 i, t} \\
& \log \left(\text { FDIN }_{i, t}\right)=\beta_{0}+\beta_{1} \log \left(\text { Nat }_{i, t}\right)+\beta_{4} X_{i, t}+\varepsilon_{3 i, t}
\end{aligned}
$$

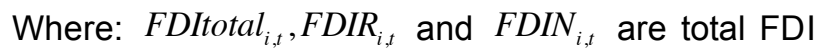
inflows, resource-related FDI inflows and non-resource FDI inflows, respectively, i represent the host country and $t$ indicates time.

Nat $_{i, t}$ denotes the rents of natural resources. $X_{i, t}$ represents the indicator of control variables (GDP per capita/PPP, institutional quality, trade openness and inflation rate), and $\varepsilon_{i, t}$ are error terms.

\section{EMPIRICAL EVIDENCE}

This section starts investigating the FDI determinants from the aggregate level's analysis from

Table 2: Panel Stationarity Test (Hardi Test)

\begin{tabular}{|c|c|c|}
\hline Variable & $\begin{array}{c}\text { Level } \\
\text { (P-Value) }\end{array}$ & $\begin{array}{c}\text { First difference } \\
\text { (P-Value) }\end{array}$ \\
\hline \hline Resource FDI & $1.6457(0.049)$ & $-0.9256(0.8227)$ \\
\hline Non-Resource FDI & $2.0028(0.022)$ & $-1.4423(0.9254)$ \\
\hline Oil Rents & $3.91(0.000)$ & $-0.7855(0.7855)$ \\
\hline Inflation rate & $2.2903(0.0110)$ & $-0.8622(0.8057)$ \\
\hline Political Instability & $9.5526(0.000)$ & $-0.1546(0.5615)$ \\
\hline Corruption Perception Index (CPI) & $10.1337(0.000)$ & $2.266(0.117)$ \\
\hline GDP per capita & $12.321(0.0000)$ & $1.323(0.0928)$ \\
\hline Labour Force & $13.57(0.0000)$ & $6.18(0.1000)$ \\
\hline Trade Openness & $11.50(0.0000)$ & $-0.215(0.8216)$ \\
\hline
\end{tabular}


Table 3: Panel Co-Integration Test

\begin{tabular}{|c|c|c|}
\hline Modified Dickey-Fuller t & 0.4517 & 0.3257 \\
\hline Augmented Dickey-Fuller t & -0.9556 & 0.1696 \\
\hline Unadjusted modified Dickey-Fuller t & -5.2005 & 0.0000 \\
\hline Kao test FDINR $=\mathbf{f}$ (Oil rents, $X$ variables) & Statistic & p-value \\
\hline Modified Dickey-Fuller $\mathrm{t}$ & -1.1645 & 0.1221 \\
\hline Dickey-Fuller t & -3.9919 & 0.0000 \\
\hline Augmented Dickey-Fuller t & -0.7647 & 0.2222 \\
\hline Modified Phillips-Perron t & 4.3744 & 0.0000 \\
\hline Phillips-Perron $\mathrm{t}$ & -15.1045 & 0.0000 \\
\hline Augmented Dickey-Fuller t & -8.4526 & 0.0000 \\
\hline Pedroni test FDIR= $\mathbf{f}$ (Oil rents, $X$ variables) & Statistic & p-value \\
\hline Modified Phillips-Perron & 4.8821 & 0.0000 \\
\hline Phillips-Perron t & -7.7118 & 0.0000 \\
\hline Augmented Dickey-Fuller & -5.2905 & 0.0000 \\
\hline
\end{tabular}

1980-2017. Then it examines the sectoral determinants of FDI (2003-2017) and analyses the possible effects of oil price fluctuations on the foreign firm's decision by sectors resource and non-resource.

To start with, the ordinary least squares (OLS) estimations, following fixed effects instrumental variable(hereafter IV-FE) regressions to study the impacts of natural resource abundance on FDI inflows in GCC countries. Table $\mathbf{4}$ indicates that natural resource rents determine the FDI inflows in GCC economies. However, the results in column 1 show that an increase in oil rent ratio by $10 \%$ causes about a $10 \%$ decrease in FDI inwards. Further, these negative effects of natural resources become smaller when we control the issue of endogeneity by performing IV-FE estimator. The oil rents coefficient in Table 4-column 2 reports that FDI inflows fall by $8.8 \%$ if oil revenues increase by $10 \%$. These results are consistent with few previous studies by Asiedu (2013), who suggested that a higher share of oil rents in GDP denotes a very low trade diversification that increases the host country's vulnerability to external shocks such as oil volatility shocks. All these elements cause macroeconomic uncertainty and consequently decrease FDI. Also, they claim that the phenomena of Dutch disease could be one more factor that explains this negative relationship.

Turning to other determinants, the estimations demonstrate that trade openness affects FDI inflows significantly and positively in GCC countries. Trade openness is anticipated to develop a business-friendly economic environment and rise investment, thus leading to extra FDI inflows. These results are in line with studies by Mina (2007), Asiedu (2002), Liu et al. (2001) and Boateng et al. (2015). The findings regarding the labour force indicate that foreign firms motivated positively by the labour force in GCC economies. The higher the economically active workforce obtains in the host economies, the higher the likelihood of inward FDI in the GCC countries. It is fairly expected that the workforce movement is not as straightforward as a capital movement.

Interestingly, market size (GDP per capita/PPP) hurts FDI inflows. This result might be coined to GCC economies as oil-exporting countries, and it is consistent with findings by Mina (2007). Whichever hypothesis is more reasonable is the subject of future research. It expected that the impact of political 
Table 4: Natural Resource and Total FDI Inflow in GCC (1980-2017)

\begin{tabular}{|c|c|c|}
\hline Independent Variables & (1) & (2) \\
\hline \multirow[t]{2}{*}{ Log (Oil Rents) } & $-0.97^{* * *}$ & $-0.88^{* * *}$ \\
\hline & $(0.240)$ & $(0.238)$ \\
\hline Log (Trade Openness) & $0.63^{* * *}$ & $0.64^{* * *}$ \\
\hline Inflation Rate & $(0.0265)$ & $(0.0257)$ \\
\hline \multirow[t]{2}{*}{ Log (labour force) } & $0.635^{\star * *}$ & $0.705^{\star * *}$ \\
\hline & $(0.113)$ & $(0.109)$ \\
\hline Log (GDP Per Capita) & $-0.332^{* * *}$ & $-0.309^{\star * *}$ \\
\hline Political Instability Index & $(0.166)$ & $(0.165)$ \\
\hline \multirow[t]{2}{*}{ Corruption Perception Index } & $4.791^{*}$ & 0.546 \\
\hline & $(2.465)$ & (1.298) \\
\hline \multirow[t]{2}{*}{ constant } & $-0.973^{* * *}$ & $-0.880^{* * *}$ \\
\hline & $(0.240)$ & $(0.238)$ \\
\hline Observations & 222 & 222 \\
\hline R-squared & 0.53 & - \\
\hline $\begin{array}{c}\text { Sargan Test } \\
\text { (p-value })\end{array}$ & - & $\begin{array}{c}4.58 \\
(0.112)\end{array}$ \\
\hline
\end{tabular}

Note: (1). Standard errors in parentheses ${ }^{* * *} p<0.01,{ }^{* *} p<0.05,{ }^{*} p<0.1$. (2) aggregate FDI data based on the UNCTACD data set during (1980-2017). (2) The endogeneity test is for testing whether the variable of interest is endogenous or not. This test based on the outcomes of the IV (xtivreg2) regression.

instability and corruption will be negative, but this effect could vary across sectors of FDI, as shown later.

Another strand of literature argues that the negative effect of a natural resource on FDI inflows is not direct effects, but rather it is attributed to crowding-out mechanisms. When foreign firms concentrated on oil sectors, production factors moved from productive sectors, such as industry and service, to the booming sector. Naturally, domestic and international capital flows go to the same sector and create a negative effect on the non-resource sector. (Poelhekke and Van der Ploeg, 2010; Poelhekke and van der Ploeg, 2013)

Now, this paper aims to go further into the previous findings and investigate the possible effects of a natural resource on resource and non-resource FDI. The regressions are summarised in Table 5 .
The OLS results in Table 5-column3 and 4 indicate our predictions; oil rents attracted more resource FDI and decreased FDI inwards to other sectors. The coefficient of 0.03 means that if oil rents increase by $10 \%$, foreign firms increase their oil investments by $0.3 \%$. Whereas the same increase in oil rents leads to about a $5.2 \%$ decrease in non-oil FDI. The negative effects of a natural resource on non-resource FDI are bigger than the positive impacts on resource FDI. It is argued that OLS estimations usually do not consider the possibly omitted variables and reverse causality among the main interest variables, so we applied an IV-FE estimator to alleviate the problem of endogeneity.

The IV-FE outcomes are reported in columns 5 and 6. The coefficient of oil rents proposes that oil rents as a proxy of natural resource endowment stimulate FDI inflows in the resource sector. The resource FDI 
Table 5: Natural Resources and Sectoral FDI in GCC (2003-2017)

\begin{tabular}{|c|c|c|c|c|}
\hline \multirow{3}{*}{ Independent Variables } & \multicolumn{2}{|c|}{ OLS Estimation } & \multicolumn{2}{|c|}{ IV Estimation } \\
\hline & (3) & (4) & (5) & (6) \\
\hline & Resource FDI & Non-resource FDI & Resource FDI & Non-resource FDI \\
\hline \multirow[t]{2}{*}{ Log (Oil Rents) } & $0.03^{*}$ & $-0.52^{\star *}$ & $0.95^{\star \star \star}$ & $-0.23^{\star *}$ \\
\hline & $(0.444)$ & $(0.227)$ & $(0.360)$ & $(0.226)$ \\
\hline \multirow[t]{2}{*}{ Inflation rate } & -0.03 & $0.05^{* *}$ & -0.019 & -0.002 \\
\hline & $(0.0366)$ & $(0.0211)$ & $(0.0161)$ & $(0.0393)$ \\
\hline \multirow[t]{2}{*}{ Log (Labour Force) } & -0.32 & $0.21^{* *}$ & $0.69^{* *}$ & 0.42 \\
\hline & $(0.220)$ & $(0.0868)$ & $(0.312)$ & $(0.761)$ \\
\hline \multirow[t]{2}{*}{ Log (Trade Openness) } & -0.27 & 0.11 & $0.82^{* * *}$ & $-0.98^{* *}$ \\
\hline & $(0.206)$ & $(0.124)$ & $(0.179)$ & $(0.438)$ \\
\hline \multirow[t]{2}{*}{ Log (GDP Per Capita) } & 0.41 & $-0.39^{*}$ & -0.25 & 0.547 \\
\hline & $(0.462)$ & $(0.216)$ & $(0.157)$ & $(0.383)$ \\
\hline \multirow[t]{2}{*}{ Political Instability Index } & 0.44 & -0.092 & 0.09 & -0.09 \\
\hline & $(0.469)$ & $(0.180)$ & $(0.520)$ & $(1.270)$ \\
\hline \multirow[t]{2}{*}{ Corruption Perception Index } & 1.34 & 0.98 & $0.49^{* *}$ & 0.008 \\
\hline & (2.428) & $(1.177)$ & $(0.203)$ & $(0.495)$ \\
\hline \multirow[t]{2}{*}{ constant } & 0.030 & $-0.517^{* *}$ & -8.24 & 1.40 \\
\hline & $(0.444)$ & $(0.227)$ & (6.939) & (16.95) \\
\hline Observations & 84 & 84 & 84 & 84 \\
\hline R-Squared & 0.18 & 0.39 & - & - \\
\hline $\begin{array}{l}\text { Sargan Test } \\
\text { (p-value })\end{array}$ & - & - & $59.74(0.101)$ & $50.10(0.351)$ \\
\hline $\begin{array}{l}\text { Endogeneity test of endogenous } \\
\text { regressors (oil rents /GDP) }\end{array}$ & - & - & $\begin{array}{c}32.93 \\
(0.000)\end{array}$ & $\begin{array}{l}12.402 \\
(0.000)\end{array}$ \\
\hline Cragg-Donald statistic & - & - & 10.265 & 12.370 \\
\hline
\end{tabular}

increases by $9.5 \%$ when oil rents go up by $10 \%$. However, FDI to other sectors (non-resource sector) reacts negatively by the presence of natural resources.

These results are in line with crowding-out effects of natural resource resources and confirm the results by Elheddad (2018), Poelhekke and Van der Ploeg (2010) and Poelhekke and van der Ploeg (2013).

It worth noting that the impact of corruption on resource-related FDI is positive. This result is interesting and indicates that foreign firms are attracted to invest in corrupt areas. This is not a surprising result, and it is in line with the study by Kolstad and Wiig (2013). This results might need more investigation in the future.

Because of the FDI concentration on the oil sector, it is worth examining the impacts of oil price fluctuations on sectoral FDI. This exercise gives a wide understanding of the risks of natural resources dependence and a lower degree of FDI diversification in GCC economies.

The findings in Table 6 display that high oil price volatility generates a substantial reduction of FDI inflows to the sector of oil. A $1 \%$ rise in oil price volatility causes a $0.5 \%$ decrease in resource-related FDI. This negative effect of oil price volatility still valid even after controlling the issue of endogeneity. Nonresource FDI, however, was impacted positively by oil price fluctuations, but this influence is not significant and is quite small. These results confirm another possible mechanism of crowding-out, and in line with studies by Van der Ploeg and Poelhekke (2009), Blattman et al. (2007) and Elheddad (2016) who claim that the volatility of natural resource prices can hurt the economic growth and investments. 
Table 6: FDI and Oil Prices Volatility

\begin{tabular}{|c|c|c|c|c|}
\hline \multirow[b]{2}{*}{ Independent Variables } & \multicolumn{2}{|c|}{ OLS Estimations } & \multicolumn{2}{|c|}{ IV Estimations } \\
\hline & $\begin{array}{c}(7) \\
\text { Resource FDI }\end{array}$ & $\begin{array}{c}(8) \\
\text { Non-resource FDI }\end{array}$ & $\begin{array}{c}\text { (9) } \\
\text { Resource FDI }\end{array}$ & $\begin{array}{c}(10) \\
\text { Non-resource FDI }\end{array}$ \\
\hline \multirow[t]{2}{*}{ Log (Labour Force) } & $0.890^{* * *}$ & 0.144 & $1.056^{\star * *}$ & 0.0940 \\
\hline & $(0.249)$ & $(0.125)$ & $(0.261)$ & $(0.132)$ \\
\hline \multirow[t]{2}{*}{ Log (GDP per capita) } & -0.239 & $0.392^{\star * *}$ & -0.255 & $0.328^{\star *}$ \\
\hline & $(0.270)$ & $(0.136)$ & $(0.281)$ & $(0.142)$ \\
\hline \multirow[t]{2}{*}{ Corruption Perception index } & $0.630^{*}$ & -0.185 & $0.596^{*}$ & -0.0483 \\
\hline & $(0.341)$ & $(0.171)$ & $(0.362)$ & $(0.183)$ \\
\hline \multirow[t]{2}{*}{ Political Instability Index } & $-0.703^{* *}$ & $-0.481^{* * *}$ & $-0.920^{* * *}$ & $-0.449^{* * *}$ \\
\hline & $(0.325)$ & $(0.163)$ & $(0.332)$ & $(0.167)$ \\
\hline \multirow[t]{2}{*}{ Inflation rate } & 0.00381 & $0.0338^{*}$ & 0.00351 & 0.0197 \\
\hline & $(0.0370)$ & $(0.0186)$ & $(0.0379)$ & $(0.0192)$ \\
\hline \multirow[t]{2}{*}{ Oil price fluctuation } & $-0.542^{* * *}$ & 0.0249 & $-0.526^{\star * *}$ & 0.0222 \\
\hline & $(0.123)$ & $(0.0620)$ & $(0.127)$ & $(0.0639)$ \\
\hline \multirow[t]{2}{*}{ Constant } & 2.465 & -0.549 & 1.835 & 0.0326 \\
\hline & $(2.836)$ & $(1.423)$ & (2.921) & $(1.475)$ \\
\hline Observations & 84 & 84 & 84 & 84 \\
\hline R-squared & 0.282 & 0.242 & - & - \\
\hline $\begin{array}{l}\text { Sargan Test } \\
\text { (p-value) }\end{array}$ & - & - & $57.78(0.130)$ & $60.57(0.08)$ \\
\hline $\begin{array}{l}\text { Endogeneity test of endogenous } \\
\text { regressors (oil rents /GDP) }\end{array}$ & - & - & $\begin{array}{c}0.07 \\
(0.77)\end{array}$ & $\begin{array}{c}0.221 \\
(0.638)\end{array}$ \\
\hline Cragg-Donald statistic & - & - & 10.26 & 12.30 \\
\hline
\end{tabular}

\section{CONCLUSION}

This study examined the impact of natural resource abundance and oil price volatility on total and sectoral FDI inflows for GCC countries. The ordinary least squares and fixed effect instrumental variable estimations were applied to study the relationship between the variables over two different periods (1980-2017) for the aggregate level of FDI and (20032017) sector-level of FDI. The empirical results show that natural resource abundance measured by oil rent/GDP ratio has influenced the total FDI inflows significantly and negatively. At the sectoral level, nonresources related to FDI inflows are deterred by natural resources, while natural resources attract more FDI in the oil sector, which supports the crowding-out hypothesis. A negative and significant association is found between resource FDI and oil price volatility.

There are two implications of our results. First, our empirical results imply that there are challenges for policymakers in their pursuit of a suitable FDI policy some of GCC. Our results support the idea of the negative effect of oil price volatility on FDI inflow. Therefore, policymakers in these countries should take a proper strategy to improve the quality of FDI inflow by diversifying FDI policies, such as focusing on the financial service sector. The tourism sector could be one more option for these countries to diversify their sources of income away from hydro-carbonic goods. Second, these economies should adopt strategies to develop institutional quality. For example, governments in these countries should include extractive firms to disclose the number of revenues that came from resource production and registered in the Extractive Industry Transparency Initiative.

Future research is needed regarding two main issues. First, investigating the crowding-out effect by expanding the sample of countries because our sample is limited to a specific region of economies. Second, one might correlate this issue with environmental quality by investigating the pollution haven hypothesis using sectoral FDI. 


\section{REFERENCE}

Alfaro, L., Chanda, A., Kalemli-Ozcan, S. \& SAYEK, S. (2004). FDI and economic growth: the role of local financial markets. Journal of international economics, 64, 89-112. https://doi.org/10.1016/S0022-1996(03)00081-3

Asiedu, E. (2002). On the determinants of foreign direct investment to developing countries: is Africa different? World Development, 30, 107-119. https://doi.org/10.1016/S0305-750X(01)00100-0

Asiedu, E. (2006). Foreign direct investment in Africa: The role of natural resources, market size, government policy, institutions and political instability. The World Economy, 29, 63-77. https://doi.org/10.1111/j.1467-9701.2006.00758.x

Asiedu, E. (2013). Foreign direct investment, natural resources and institutions. International Growth Center London: London School of Economics and politics.

Bernanke, B. S. (1983). Irreversibility, uncertainty, and cyclical investment. The Quarterly Journal of Economics, 98, 85-106. https://doi.org/10.2307/1885568

Blattman, C., Hwang, J. \& Williamson, J. G. (2007). Winners and losers in the commodity lottery: The impact of terms of trade growth and volatility in the Periphery 1870-1939. Journal of Development Economics, 82, 156-179. https://doi.org/10.1016/j.jdeveco.2005.09.003

Boateng, A., Hua, X. P., Nisar, S. \& Wu, J. J. (2015). Examining the determinants of inward FDI: Evidence from Norway. Economic Modelling, 47, 118-127. https://doi.org/10.1016/j.econmod.2015.02.018

Bokpin, G. A., Mensah, L. \& Asamoah, M. E. (2015). Foreign direct investment and natural resources in Africa. Journal of Economic Studies, 42, 608-621. https://doi.org/10.1108/JES-01-2014-0023

Borensztein, E., De Gregorio, J. \& Lee, J.-W. (1998). How does foreign direct investment affect economic growth? Journal of International Economics, 45, 115-135. https://doi.org/10.1016/S0022-1996(97)00033-0

Canton, E. \& Solera, I. (2016). Greenfield Foreign Direct Investment and Structural Reforms in Europe: What Factors Determine Investments? Luxembourg: European Economy Discussion Papers.

Corden, W. M. \& Neary, J. P. (1982). Booming sector and deindustrialisation in a small open economy. The economic journal, 825-848. https://doi.org/10.2307/2232670

Dunning, J. H. (1998). Location and the multinational enterprise: a neglected factor? Journal of International Business Studies, 45-66. https://doi.org/10.1057/palgrave.jibs.8490024

Dunning, J. H. (2001). The eclectic (OLI) paradigm of international production: past, present and future. International journal of the economics of business, 8, 173-190. https://doi.org/10.1080/13571510110051441

Economist (2015). The twilight of the resource curse? Africa's growth is being powered by things other than commodities. The Economist.

Eheddad, M. M. (2016). Natural Resources and FDI in GCC Countries. International Journal of Business and Social Research, 6, 12-22. https://doi.org/10.18533/ijbsr.v6i7.977
Eheddad, M. M. (2018). What determines FDI inflow to MENA countries? Empirical study on Gulf countries: Sectoral level analysis. Research in International Business and Finance, 44, 332-339.

https://doi.org/10.1016/j.ribaf.2017.07.101

Froot, K. A. \& Stein, J. C. (1989). Exchange rates and foreign direct investment: an imperfect capital markets approach. National Bureau of Economic Research Cambridge, Mass., USA. https://doi.org/10.3386/w2914

Hadri, K. (2000). Testing for stationarity in heterogeneous panel data. The Econometrics Journal, 3, 148-161. https://doi.org/10.1111/1368-423X.00043

Hamilton, J. D. (2003). What is an oil shock? Journal of Econometrics, 113, 363-398. https://doi.org/10.1016/S0304-4076(02)00207-5

HAYAT, A. 2018. FDI and economic growth: the role of natural resources? Journal of Economic Studies, 45, 283-295. https://doi.org/10.1108/JES-05-2015-0082

Henry, C. (1974). Investment decisions under uncertainty: the" irreversibility effect". The American Economic Review, 64 1006-1012.

Kolstad, I. \& Wiig, A. (2013). Digging in the dirt? Extractive industry FDI and corruption. Economics of Governance, 14, 369-383. https://doi.org/10.1007/s10101-013-0133-2

Lipsey, R. E. \& Weiss, M. Y. (1981). Foreign production and exports in manufacturing industries. The review of Economics and Statistics, 488-494. https://doi.org/10.2307/1935843

Liu, X., Wang, C. \& Wei, Y. (2001). Causal links between foreign direct investment and trade in China. China Economic Review, 12, 190-202. https://doi.org/10.1016/S1043-951X(01)00050-5

Mina, W. (2007). The location determinants of FDI in the GCC countries. Journal of Multinational Financial Management, 17, 336-348.

https://doi.org/10.1016/j.mulfin.2007.02.002

Mohamed, S. E. \& Sidiropoulos, M. G. (2010). Another look at the determinants of foreign direct investment in MENA countries: An empirical investigation. Journal of Economic Development, 35, 75. https://doi.org/10.35866/caujed.2010.35.2.005

Poelhekke, S. \& Van Der Ploeg, R. (2010). Do Natural Resources Attract FDI? Evidence from non-stationary sector level data https://doi.org/10.2139/ssrn.1950092

Poelhekke, S. \& Van Der Ploeg, R. (2013). Do Natural Resources Attract Nonresource FDI? The Review of Economics and Statistics 95, 1047-1065. https://doi.org/10.1162/REST_a_00292

Toews, G. \& Venzina, P.-L. (2016). Resource Discoveries and FDI Bonanzas. Oxford Centre for the Analysis of Resource Rich Economies, University of Oxford.

Van Der Ploeg, F. \& Poelhekke, S. (2009). Volatility and the natural resource curse. Oxford Economic papers, 61, 727-760. https://doi.org/10.1093/oep/gpp027

Wheeler, D. \& Mody, A. (1992). International investment location decisions: The case of US firms. Journal of International Economics, 33, 57-76. https://doi.org/10.1016/0022-1996(92)90050-T

Received on 28-03-2020

Accepted on 01-05-2020

Published on 04-06-2020

\section{DOI: https://doi.org/10.6000/1929-7092.2020.09.22}

(C) 2020 Elheddad et al.; Licensee Lifescience Global.

This is an open access article licensed under the terms of the Creative Commons Attribution Non-Commercial License (http://creativecommons.org/licenses/by-nc/3.0/) which permits unrestricted, non-commercial use, distribution and reproduction in any medium, provided the work is properly cited. 